\title{
Crisis or Adaptation - Reconsidered: A comparison of East and West German fertility patterns in the first six years after the 'Wende'
}

\author{
Michaela Kreyenfeld ${ }^{\mathrm{H}}$
}

\begin{abstract}
Similar to other Eastern European countries, East Germany experienced a rapid decline in period fertility rates after the fall of communism. This decline has been discussed along the lines of a 'crisis' and a 'adaptation' to western demographic patterns. The aim of this paper is twofold. Firstly, we discuss the factors which foster and hamper a convergence of fertility behavior in East and West Germany. Secondly, we use data from the German micro-census to analyze the fertility patterns of the cohorts born 1961-1970. Major results from our empirical analysis are that East Germans who are still childless at unification are more rapid to have their first child in the subsequent years than comparable West Germans. However, regarding second parity births, the pattern reverses. Here, East Germans display a lower transition rate than their counterparts in the West.
\end{abstract}

H The view expressed in this paper is my own. It does not necessarily reflect the views of the Max Planck Institute for Demographic Research. Authors' correspondence address: Max Planck Institute for Demographic Research, Doberaner Str. 114, 18057 Rostock, Germany. Telephone: +49-381-2081-136 Fax: +49-381-2081-436 Email: kreyenfeld@demogr.mpg.de. 


\section{Introduction}

Similar to other Eastern European countries, East Germany experienced a drastic and raid decline in period fertility rates after the fall of communism (e.g., Kharkova and Andreev 2000; Kučera et al. 2000; Frejka and Calot 2001; Philipov 2002). While there were still 180,000 births in 1990 , there were only 110,000 a year later, which is a drop in the number of births by about 40 percent over the period of a single year. During this time, migration from East to West Germany had reduced the population size in the East considerably. In the period 1989 to 1991 alone, about one million East Germans had migrated to the West (Statistisches Bundesamt 2001a). Massive East to West migration has clearly distorted the usefulness of the annual number of births as a fertility indicator. However also the total fertility rate (TFR), which standardizes for population size and age structure, shows a drastic reduction in fertility. As can be seen from the Figure 1, the East German TFR dropped from 1.5 in 1990 to 1.0 in 1991, reaching its lowest level of 0.8 in the years 1992 to 1995 . Since then the East German TFR has steadily increased, but has not reached West German fertility levels yet.

The decline in fertility rates after unification has motivated researchers to conclude that the East German society is undergoing a severe social and economic crisis (e.g., Eberstadt 1994; Witte and Wagner 1995; Dorbritz 1997). Mau (1994, p. 206) considers the East German society as being in state of 'anomie' and the fertility decline a response to it. Eberstadt (1994) believe that the low East German birth rates mirror the state the East German economy has been in, where couples do not commit themselves to the responsibilities of parenthood in uncertain and unstable times. Fleischhacker (1994, p. 43) draws analogues to demographic developments during wartime. Others have also 
talked about a 'birth strike' (Gebärstreik), in which East German women are assumed to forgo parenthood as part of a collective protest (e.g., Adler 1997, p. 6) (for a critical discussion, see Dölling et al. 2000).

[Figure 1 about here]

Although, there is a consensus that in the immediate time after unification, East Germans have been undergoing a fertility crisis, there was some dispute on the general course of East German fertility. In this context, it makes sense to contrast a crisis and an adaptation hypothesis (e.g., Mau 1994; Richter 1993; Witte and Wagner 1995; Mau and Zapf 1998; Schaich 1998). Advocates of the 'crisis hypothesis' argue that unfavorable economic constraints keep East Germany’s fertility below West German levels for the foreseeable future. Supporters of the 'adaptation hypothesis' are more optimistic in this respect. They argue that although the economic situation has been lagging behind, individuals in the neue Länder (new federal states) are subject to very similar institutional constraints in the 1990s as their counterparts in the alte Länder (old federal states). Assuming that family policies, tax regulations and ultimately the entire set up of the welfare system are the primary parameters for fertility decisions, one would expect that East German fertility converges towards West German levels as soon as the economic situation relaxes. 


\section{Period Fertility Indicators}

Advocates of the 'crisis hypothesis' have often taken the drop in annual birth rates as an unmistakable sign of an East German fertility crisis (Eberstadt 1994; Witte and Wagner 1995; Beck-Gernsheim 1997). This interpretation might have been correct for the time around unification, however it is not applicable for the time thereafter. It is well known that period fertility indicators are easily subject to misinterpretation, particularly when there are changes in the timing of childbirth (e.g., Bongaarts and Feeney 1998; Kohler and Philipov 2001). A decline in period fertility rates can indicate a decline in lifetime fertility, but it might just as well be a postponement of motherhood to higher ages. This aspect is of particular importance in the case of East Germany. Compared to other western European countries, the mean age of women at childbirth was very low in East Germany. In 1989, the mean age at childbirth was 24.7 (Statistisches Bundesamt 1999). On the other hand, West Germany displayed --with 28.3 years of age in the year 1989-a rather high age at childbirth in cross-national comparison (Statistisches Bundesamt 2001a).

The considerable difference in the age at childbirth between East and West Germans is crucial in understanding the 'East German fertility decline'. Even if East German women, who were childless in 1990, temporarily gave up on childbearing during the upheavals of unification, they were generally young enough to postpone childbearing to a later phase in their lives without reaching the biological limits of fertility. In other words, what looks like a fertility crisis from the point of period fertility indicators could in fact be a postponement of childbirth to West German age levels. The crucial question in this context is, whether the drop in the TFR indicates a 'fertility crisis' indeed or whether it is part of an 'adaptation' to the West German fertility pattern. In order to 
address this aspect, one needs to take a cohort perspective on fertility.

Even though several researchers have noted that timing effects might be an important factor for the drop in the TFR (e.g., Conrad et al. 1996, p. 339; Dorbritz 1997, p. 239), it has remained unclear what this aspect precisely means for period fertility rates. Hitherto, the question of how close East and West German fertility has come has not been addressed and, most importantly, it remains unclear how the 'timing issue' fits into the ‘crisis' versus ‘adaptation' hypothesis.

\section{Aim and structure of the paper}

The aim of this paper is compare the fertility behavior of the East and West German birth cohorts 1961 to 1970 from the life course perspective (Elder 1985; Mayer 1997). By 'life course perspective', we understand that we (i) use cohort instead of period data, (ii) analyze the transition to the different birth parities separately, and (iii) pay particular attention to the way that unification cut into the life courses and the 'fertility careers' of the respondents. We picked the birth cohorts 1961-1970 who were respectively ages 20-29 at unification. They had entered childbearing age before unification, but were still at risks of childbirth thereafter, i.e. their behavior should have primarily defined the fertility pattern of the 1990s. Furthermore, members of these cohorts had just entered the labor market around the time of unification and their employment careers were therefore most severely affected by the economic upheavals during this times (Sackmann and Wingens 1996; Mayer et al. 1999). In other words, if the economic situation has affected East German fertility, it should be most pronounced for these cohorts. 
The remainder of this paper is structured as follows. In Part 2 we redefine the 'crisis' versus 'adaptation' hypothesis for the analysis of fertility from the life course perspective. We furthermore discuss some major factors that foster and hamper a convergence of fertility behavior in East and West. Part 3 comprises the empirical analysis of the transition pattern to the first and second child using life table techniques. Part 4 contains the concluding remarks.

\section{Theoretical Considerations}

\subsection{The Life Course Perspective}

Taking a life course perspective on fertility draws attention to the question of how East and West Germans time their first and space their subsequent children. From this perspective, one can talk of an 'adaptation’ to West German pattern when East Germans have their first child at comparable ages as West Germans and when they space their subsequent children in a similar manner.

From previous studies, we know that the percentage of (final) childlessness in West Germany is roughly 25 percent and the median age at first birth 28 years of age (e.g., Dorbritz and Schwarz 1996; Kreyenfeld and Huinink 2002). Given that East Germans postpone first parenthood above this age level or remain childless to a larger extent, there would be an indication of a 'crisis-related' fertility behavior. Vice versa, if they have their first child at comparable ages, one could talk of an 'adaptation' to West German first birth patterns. 
In order to describe second birth patterns, one usually uses the spacing of the first and the second child and we follow this convention here. In West Germany, roughly 75 percent of the women who have a first child proceed to have a second child, 'typically' three years after the first child (e.g., Huinink 1989; Kreyenfeld 2002). Against this background, we define an 'adaptation' as a convergence towards this spacing pattern.

An issue, which we have not address so far is, how unification 'cut' into the life courses and fertility careers of East and West Germans. Since fertility behavior in the former GDR and FRG differed substantially, particularly regarding the transition pattern to the first child, there was a relatively larger fraction of East Germans (of the cohorts 19611970) who had already set up a family by the year 1990. This involves that the East and West German population at risk of childbirth differed at the eve of unification. If one takes the East and West German birth cohorts 1961-1970 and compares their fertility behavior after unification, one needs to take into consideration the differences in their fertility histories prior to that date. The implications of this aspect for the East-West comparison of fertility is an issue, we will directly address in the empirical analysis in Part 4. In the following, we first discuss major factors, which foster and hamper a convergence of fertility behavior in East and West Germany

\subsection{East-West differences in constraints and attitudes in the 1990s}

Compared to other formerly socialist countries, East Germany has experienced the most rapid and radical transformation from a centrally planned to a market economy. Although the privatization process was almost completed by the middle of the 1990s, 
wages and productivity in the eastern states are still behind western levels (Lange and Pugh 1998; Schwarze and Wagner 2001). The unemployment rate in the year 2000 is 17.4 percent in the East, while it is 7.8 percent in the West (see Figure 2). The average hourly wage of a male East German worker in the industry sector (Arbeiter im produzierenden Gewerbe) is 10.50 Euro in the year 2000, or only 69 percent of the wage of West German worker who earns 15.13 Euro on average (Statistisches Bundesamt 2002). Assuming that economic factors are important for fertility, one would assign the high unemployment rates and the low wages a key role when explaining East-West differences in fertility behavior (e.g., Eberstadt 1994; Witte and Wagner 1995).

[Figure 2 about here]

Although the economic situation certainly stands out as exceptional, there are other East-West differences --in attitudes as well as in institutional constraints-- which have outlasted unification. The most relevant ones for explaining fertility are presumably the differences in the public provision of day care, the attitudes towards women's employment and the ones towards family life. In contrast to the economic situation, which is widely expected to suppress East German fertility, these factors could explain a more rapid family formation in the East. In the following, we discuss these aspects in more detail. ${ }^{1}$ 


\section{Public day care}

There was a general believe that the day care system of the former GDR would either be privatized in the course of unification or at least drastically cut down. A 'lack' or a 'shortage' of public day care was therefore generally expected (e.g., Nauck and Joss 1995, p. 25; Rindfuss and Brewster 1996, p. 273; Adler 1997, p. 44; Kopp 2000, p. 109). However, the development in East Germany took a different turn. Throughout the 1990s, day care coverage in the new federal lands has remained relatively high. For example, in 1998, the availability ratio for places in the Krippe (care for children ages 0 -3) is almost 40 percent in East, but only 4 percent in the West (see Table 1). There is complete coverage of full-time day care for preschool children (ages 4-7) in the East. In the West, the availability ratio is roughly 20 percent only.

The reasons for the persisting differences in the provision rate of public day care are hard to track down. However, it is clear that it partially relates to the structure of German childcare policy, which is primarily a local responsibility (Kreyenfeld et al. 2002). Furthermore, the high coverage of public day care might also be considered as an 'inheritance' from GDR-times, when a network of public day care centers was established (Hank et al. 2001). In contrast to other family policies of the former GDR, which were swiftly abolished in the course of unification, the day care infrastructure was taken over by the local communities and was only gradually cut down. Since birth rates and therefore the children to be cared for also declined, provision rates remained relatively high.

[Table 1 about here] 


\section{Attitudes towards mother's employment and family life}

Closely related to the still high coverage of public day care are the persisting differences in the attitudes towards women's employment. Former GDR policies were directed towards integrating women into working life, the provision of places in public daycare being a major part of it. Other policies are, for example, maternity leave regulations which, by FRG-standards, provided a relatively high income replacement level (Frerich and Frey 1993; Höhn and Schwarz 1993; Trappe 1995; Trappe and Rosenfeld 1998; Trappe and Rosenfeld 2000). Although, GDR-family policies had been replaced in favor of the West German system in 1990, they had nevertheless instilled very pronounced attitudes towards the labor market participation of women, particularly regarding those with children. As a legacy from former socialist times, East German women still more often consider women's employment and economic independence as a matter of course than their more traditional counterparts in the West who generally believe that women should reduce their working hours when they have small children (e.g., Braun et al. 1994; Konietzka and Kreyenfeld 2002).

It has also been argued that the GDR-system supported a very favorable attitude towards children and family-life (Richter 1993, p. 2; Störtzbach 1994, p. 160, BeckGernsheim 1997, p. 63). East Germans were subject to a repressive system for almost half a century, which, so the line of reasoning, they responded to by seeking fulfillment in private life (Wendt 1991, p. 266; Frerich and Frey 1993, p. 392; Mau 1994, p. 199). Although the political set-up changed with unification, East Germans are still considering children and family life as a more essential part of their life courses. 
Particularly if one undertakes an East-West comparison of fertility, it seems vital to find out how persistent preferences are towards changes on the macro level of society. How lasting is the strife for economic independence, being confronted with the new family policies and labor market institutions? Did the cohorts that were socialized during GDR-times gradually change their attitudes over their life courses? Will only the subsequent cohorts that were socialized after unification adopt the 'new' (but traditional) attitudes? Or are preferences, even across cohorts, rather persistent against change?

Table 2 displays the attitudes towards women's employment and family life based on estimation of the ALLBUS survey (for details on the ALLBUS, see Koch et al. 2001). The ALLBUS is a repetitive cross-sectional data set, which does not allow investigating changes in attitudes over the life course. Nevertheless, the table covers the years 1992, 1996 and 2000 and therefore gives some idea on the persistence of attitudes over time. Since we only select respondents of the cohorts 1961-1970, the table also gives some idea on changes of attitudes over the life course.

[Table 2 about here]

The table supports the view of strong East-West differences in the attitudes towards mother's employment. In 2000, 65 percent of the respondents (of the birth cohorts 1961-1970) in the alte Länder agree that a child will suffer when the mother is employed. In the neue Länder, this only applies to 33 percent. Eight years earlier, respectively in the year 1992, the situation was fairly the same. A more favorable 
attitude towards mother's employment does not necessarily influence fertility in a positive way. However, one has to relate it to the public day care system, which provides East German women substantially better opportunities to combine childrearing and employment. 'Work oriented' women in the East face relatively favorable constraints to proceed with their employment career after childbirth and should therefore encounter a higher fertility than their counterparts in the West. Possibly, one might even argue that the high coverage of public day care provides East German couples completely different opportunities to organize working and family life, contributing to a distinct structure of gender relations and employment patterns.

Compared to the relative persisting differences towards mother's employment, the differences in the attitudes towards family life have converged slightly by the end of the 1990s. While in 1992, only 57 percent of the West Germans (of the cohorts 1961-1970) stated that they need a family to lead a happy life, this applied to 73 percent of their East German counterparts. Until 2000, the respective fraction has increased to 67 percent in the western and to 77 in the eastern states.

In sum, apart from the glaring differences in the economic situation, there are other persisting differences between the alte Länder and the neue Länder. If one primarily focuses on the economic situation (and assumes that high unemployment and low wages influence fertility negatively), there would indeed be no reason to expect an 'adaptation' of East and West German fertility in the 1990s. On the other hand, a higher coverage of children's day care and a higher preference for children are parameters, which should contribute to an earlier family formation in the East, even though unfavorable economic parameters will work in the opposite direction. 


\section{Data and method}

\subsection{The German micro-census}

In the following, we compare the transition pattern to the first and the second child for the cohorts 1961-1970. For this analysis, we use data from the scientific-use file of the 1997 micro-census (Schimpl-Neimanns 2002). The German micro-census is a onepercent sample of the population living in Germany. The scientific-use file of the micro-census is a 70 percent sample of this sample, respectively a 0.7 percent sample of the population living in Germany. The scientific use file of the micro-census for the year 1997 contains roughly 500,000 respondents.

One of the major advantages using the micro-census, compared to other survey data sets, is that it contains a relatively large sample size, which also allows for the analysis of single birth cohorts. Furthermore, the data set is a highly representative sample for the population living in Germany. Since respondents are basically legally requested to fill in the questionnaire, there is relatively little non-response (Schimpl-Neimanns 2002).

The major drawback of the German micro-census is however that it does not survey the 'fertility history' of the respondents. This means that we have to reconstruct the fertility history on the number of children who live in the mother's household at the date of interview. This involves a variety of problems, most importantly, we are not able to identify children who are not living anymore in the household of the respondents. For children who live in their mother's household, the micro-census provides information on the relationship to other cohabiting family members (Familienzusammenhang). This allows us to identify the age at childbirth and the parity of a child. It is however not 
possible to distinguish biological children from step- or adopted children. As noted before, children who have already moved out of the parental home or have died can neither be identified. Comparisons with other data set show, however, that women age 36 and younger, the percentage of children who do no longer live with their mothers is relatively small (Kreyenfeld and Huinink 2002; Schimpl-Neimanns 2002).

The other important drawback of the micro-census is that the most recently available publicly available data set is from the year 1997. Other data sets, such as the German Family Survey (Familiensurvey) or the German Socio-Economic Panel (SOEP), provide the fertility histories of the respondents up to the year 2000. These data sets do, however, not contain a sufficiently large sample size for a description of the fertility patterns in East Germany by single birth cohorts (Kreyenfeld and Huinink 2002). German vital statistics would not be instructive here, either, most importantly because they do not distinguish by the biological parity of the children.

Since the micro-census was conducted already in the beginning of the year 1997, we can only study the fertility development until the middle of the 1990s. It neither allows us to investigate 'completed' fertility, since the members of the cohorts 1961-1970 were only between the ages 27 to 36 at the date of interview. Nevertheless, the data set still provides a sufficiently long time period after unification to study the timing of first and second children.

As said before, for our analysis we are only selecting women of the birth cohorts 19611970. Other minor selections are the following: We are only selecting respondents who live in private household. We respectively omit respondents who live in institutions such as old people's homes or asylums. We do not consider respondents who gave birth 
to a first child before age 17. Per cohort of women, there are roughly 600 East and 2,5000 West German women in our sample (see Table A1, which gives a more detailed overview on the sample size).

\subsection{Procedure}

Our analysis is purely descriptive; the methodological tools used are survival curves and hazard rates, calculated by the life table method. The first part of the analysis deals with the transition to first child, the second one with the transition to the second child.

For the analysis of first births, the 'time scale' is the age of the woman. In a first step, we describe the first birth pattern for single East and West German birth cohorts. In order to investigate the fertility pattern after unification, we then select respondents who were childless in 1990 and analyze their transition pattern to the first child.

For the analysis of second births, the 'time scale' is the spacing of the first and the second child. In the first part, we select women who gave first birth before unification and we censor the cases in the year 1990. This investigation basically reveals the second birth pattern in the old FRG and GDR. In the second part, we analyze the second birth pattern after unification by selecting women into our sample who had their first children after 1990. In the last step, we perform a separate analysis for respondents who had a first child just around the time of unification, i.e. in the years 1987 to 1992. In this part, we also discuss the problems involved with comparing the spacing of children in East and West Germany without simultaneously taking into account differences in the age at first birth. 


\section{Analysis}

\subsection{The first child}

Figure 3 displays the survival curves for the transition to the first child for the cohorts 1961-1970. Let us first describe the situation for West Germany (dotted line) in order to get an idea on the fertility pattern, which the East is expected to converge to. For the birth cohort 1961, the median age at first birth (i.e., the age when 50 percent of the respondents have become mothers) is roughly 27 in the former Federal Republic of Germany. At age 35, there are still 25 percent who do not have any children yet. Given that there are only few women who have their first children past age 35, the 'final' percentage of childless women in the alte Länder is 25 percent, which is in line with findings from other studies (see e.g., Dorbritz and Schwarz 1996). Across cohorts the median age at first birth increases. While it is 27 years of age for the cohort 1961, it is age 29 for the cohort 1964.

In the East, the median age at first birth is about 22 years of age for the birth cohort 1961. Since these cohorts were age 29 at unification, they mirror the GDR-fertility pattern still. The subsequent East German cohorts are substantially postponing first parenthood, compared to their predecessors. For example, the median age at first birth is age 26 for the birth cohort 1970, which is four years higher than for the birth cohort 1961.

A postponement of childbirth to higher ages was largely expected in the course of unification. The intriguing question is whether women in the new federal states are postponing first birth above West German age levels and whether they remain childless 
to a larger extent. This question can however only partially be addressed based on the survival curves. In order to get a more comprehensive picture, we calculate the survival curves for respondents who were still childless at the end of 1990. Furthermore, we estimate the hazard rates for the survival curves displayed in Figure 3.

[Figure 3 about here]

\section{Transition to the first child after unification}

If one compares the fertility behavior of East and West Germans (of the cohorts 19611970) after unification, one has to take into account that childless East Germans are a more highly selected group in 1990. For the birth cohort 1968, for example, 55 percent of the women in the neue Länder are childless in 1990, which applies to 85 percent among their counterparts in the alte Länder (Figure 3, Panel 5). Related to this, one could imagine that the relative proportion of infertile respondents, or respondents with a strong preference to remain childless is higher in the eastern German sample. Due to such unobserved characteristics, one would expect a slower transition rate to the first child for the remaining sample.

However, one finds the opposite pattern. As can be depicted from Figure 4 (Panel 4-6), East Germans of the cohorts born 1965-1970 are faster having their first child after unification than their West German counterparts. ${ }^{2}$ Figure 5, which displays the respective hazard rates, supports this view. At unification, there is a strong and sizeable 'period effect' of unification in the eastern states. This effect is very striking compared 
to the GDR-fertility pattern. However, if compared to the western pattern, this 'period effect' is not serious at all. East German first birth risks stay above West German levels even in the immediate years after unification. For example, for the birth cohort 1968, first birth risks are significantly higher at age 23 (respectively in 1991) for women in the neue Länder than in the alte Länder. ${ }^{3}$ This is peculiar if one takes into account that children, who were born in 1991, were mostly conceived in 1990, i.e. during a time when the social and economic uncertainty was particularly high.

For the cohorts born 1961-1964, one observes the expected slower transition to the first child for the women who live in the new federal lands. Here, one has to consider that less than 25 percent of the members of the East German cohorts were childless at unification. As briefly mentioned above, the expected ratio of childless women is around 25 percent for West Germany. East German cohorts born in 1964 or earlier reached a lower level of childlessness in 1990 already (Panel 2 in Figure 3). This also involves that the ratio of childlessness cannot increase above West German levels for the cohorts born 1964 or earlier, even if those East German women who were childless at unification had completely forgone parenthood in the subsequent years. This is however not the case, i.e. East German women of the cohorts 1961-1964 continued to have children in the 1990s. At censoring (at the end of the year 1996), the final ratio of childless women is only slightly more than 10 percent, which is close to the levels of childlessness found in the former GDR (see e.g., Dorbritz and Schwarz 1996).

In sum, for the birth cohorts 1964 and older there is no reason to expect that childlessness would increase to West German levels. For the younger cohorts, it is too early to predict a final percentage of childless women. However, East German are faster having their first child after unification. Against this background, one can very 
well suspect that the final ratio of childlessness will not increase above western levels.

[Figure 4 about here]

[Figure 5 about here]

\subsection{The second child}

We now address the transition pattern to the second child. Panel 1 in Figure 6 displays the survival curve for the time prior to 1990 . Women in the former GDR were slightly less rapid to have their second child than their counterparts in the former FRG. The final progression ratio is --with 75 percent--, however, fairly the same. Panel 2 in Figure 6 displays the respective hazard rates, which also show the wider spacing of the second child in the East. It should however be noted that although East Germans spaced their first and second children further apart, they were nevertheless younger at second birth than their counterparts in the FRG.

Figure 7 displays the second birth pattern for the time after unification. For this part of the analysis, we only selected women who have given birth to their first children after 1990. The most glaring aspect this figure reveals is that second birth risks in the eastern states basically collapse after unification. The hazard rates are wide under West German levels. The survival curves suggest that five years after the birth of the first child, there are still 70 percent who do not have a second child yet. Among the West 
German sample, this amounts to only 45 percent. In other words, before unification there had been minor East-West differences in the spacing of the first and the second child. After unification, the 'spacing behavior' in the new federal lands strongly differs from the one in the old federal lands. East German women are exceptionally reluctant to have a second child.

[Figure 6 about here]

[Figure7 about here]

\section{Transition to the second child by 'first child cohorts'}

In the next step, we display the transition pattern to the second child for 'first child cohorts'. By 'first child cohorts', we understand a group of women who had given birth to their first children in the same year. By this procedure, we can more clearly show how unification affected the spacing pattern.

Before we analyze the spacing pattern of different 'first child cohorts', we discuss the problems involved with this procedure. Since we are selecting women who had their first child in a particular year and since we are only dealing with the birth cohorts 19611970, we automatically select women who had their first child at a particular age. For example, when we select women who had given birth to the first child in 1990, these women were at a maximum age 29 at first birth. The sample therefore comprises women who --by West German standards-- had a first child relatively early in life. ${ }^{4}$ Since the age at first birth has some impact on the spacing of the second child (see e.g., 
Huinink 1989; Kreyenfeld 2002), there is some bias involved here. We do, however, not take this aspect into account. Neither do we address East-West differences in the age at first birth.

Let us first describe the spacing pattern of women who had their first child before unification, i.e. who had their first child in the years 1987, 1988 or 1989 . Unification basically 'cut' into the fertility careers of these women and we assume a decline in second birth risks at unification. Since women in the former GDR were, however, relatively young at first birth, there might be a 'recuperation' of second birth in the period thereafter. In other words, particularly women who just had a first child before unification might display a very wide spacing of the first and the second child.

However, this view is not completely supported by our analysis. As can be seen from Figure 8 and Figure 9, East German women display an astonishingly low transition rate to the second child. There is drastic 'period effect' at unification and the hazard rates do not --contrary our assumption-- 'recuperate' at a later stage. For example, for the respondents who had their first child in 1989, second births risks are substantially below West German levels in the years 1990-1993 (i.e., when the first child is ages 1-4), but also thereafter they remain lower.

Let us now turn to the second birth pattern of women who had their first child after unification, i.e. in the years 1990, 1991 and 1992. For these women, it is difficult to project a second birth pattern. On the one hand, they might have most harshly been affected by the upheavals of unification, since they had just entered the phase of being at risk of second birth in the early 1990s. On the other hand, they already had their first child in unstable times and might therefore be less reluctant to have a second child then 
as well.

As can be depicted from Panel 4 to Panel 6 in Figure 9, the first assumption applies. East Germans who have given birth to their first child in 1990, 1991 or 1992 display a much slower transition rate to the second child than their counterparts in the West.

In sum, East German women are considerably more reluctant to have second children after unification. The cohorts under consideration are still of childbearing age at the date of censoring and therefore one cannot rule out that there will eventually be a 'recuperation' of second births at the end of the 1990s. This would, however, involve and enormous and unprecedented increase in the spacing of second children.

[Figure 8 about here]

[Figure 9 about here]

\section{Conclusion}

East Germany has frequently been termed as an ideal 'natural experiment' to investigate how a population responds to a rapid change of institutional constraints and how well and how fast it adjusts to the new conditions (e.g., Witte and Wagner 1995, p. 387). The two very contrasting societies of the FRG and the GDR have been united within a common institutional framework overnight. This common institutional framework was, with only small exceptions, the one of the former West Germany. Given that East 
Germans are now subject to similar institutional constraints, one would expect a convergence of East and West German fertility patterns, as soon as the economic situation in the eastern states reaches parity with the one in the western states. In this context, the 'crisis' versus 'adaptation' hypothesis have been put forward as two contrasting scenarios for the fertility development in post-communist East Germany. While the 'crisis hypothesis' suggests that the economic situation in the East will dominate East German behavior and continuously push fertility below western levels, the 'adaptation hypothesis' more strongly focuses on the similarities in institutional constraints and projects a convergence of East and West German behavior.

In the first part of the paper, we discussed the factors, which should, despite the legal and political unification of the formerly two countries, contribute to persistent EastWest differences in behavior. On the one hand, the economic situation is still lagging behind and should contribute to continuously lower fertility rates. On the other hand, there are aspects, such as a higher availability of public day care and a higher preference for children and family life, which should foster family formation.

In our empirical analysis, which was conducted with the 1997 micro-census, we analyzed the transition to the first and second child for the cohorts 1961-1970, using life table techniques. Our major finding is that East Germans who were childless in 1990 are faster to have a first child in the subsequent years than their counterparts in the West. Counter to general expectations, women in the new federal states of Germany are still slightly younger at first birth than women in the old federal lands. However, for second parity births the pattern reverses. East Germans are substantially less likely to have a second child and equally important, the relatively low second birth risks are not restricted to the years immediately after unification, but they have also remained low 
thereafter.

One main conclusion one can draw from this is that it is highly problematic to summarize the fertility behavior in post-unification East Germany under general concepts such as ‘crisis’ and ‘adaptation'. The parity and cohort specific analysis, we conducted in this paper, shows a very divergent pattern for first and second births. While East Germans still have the first child at younger ages, which might be compatible with the idea of an 'adaptation', the second birth behavior seems 'crisisrelated', if compared to the West German pattern.

The paper has to leave a lot of issues unresolved, though. Firstly, we used the West German fertility pattern as a benchmark. In line with other studies, we characterized East German fertility as 'crisis related' when it lacks behind West German levels. Obviously, there is little reason to believe that the West German fertility pattern is a particularly 'normal' and 'uncomplicated' reference group. West Germany’s fertility rates have been one of the lowest in Europe. If East German fertility converges towards the West German levels, it converges towards an exceptionally low one. The most intriguing question in this context is which are the parameters, which make East Germans postpone first parenthood to high West German ages, and which are the factors that suppress second births? Possibly, one could argue that economic constraints are more important for the decision to have a larger family, while first birth decisions might be less affected by them. However, in order to answer these questions, a microlevel analysis, which links economic parameters to fertility decisions, is ultimately needed. 


\section{Acknowledgment}

For valuable comments we would like to thank Dirk Konietzka and Gunnar Andersson. 


\section{References}

Adler, Marina A. 1997. "Social change and decline in marriage and fertility in Eastern Germany”, Journal of Marriage and the Family 59(1): 37-49.

Beck-Gernsheim, Elisabeth. 1997. “Geburtenrückgang und Kinderwunsch - die Erfahrung in Ostdeutschland”, Zeitschrift für Bevölkerungswissenschaft 22(1): 59-71.

Bongaarts, John and Griffith Feeney. 1998. "On the quantum and tempo of fertility”, Population and Development Review 24(2), 271-291.

Braun, Michael, Jacqueline Scott and Duane F. Alwin. 1994. "Economic necessity or self-actualization? Attitudes toward women's labour-force participation in East and West Germany”, European Sociological Review, 10(1): 29-47.

Brewster, Karin L. and Ronald R. Rindfuss. 2000. “Fertility and women’s employment in industrialized nations”, Annual Review of Sociology 26: 271-296.

Conrad, Christoph, Michaela Lechner and Welf Werner, 1996. "East German fertility after unification: Crisis or adaptation”, Population and Development Review 22(2), 331-358.

Deutsches Jugendinstitut. 1993. Tageseinrichtungen für Kinder. Informationen, Erfahrungen, Analysen, München: Deutsches Jugendinstitut.

Deutsches Jugendinstitut. 1998. Tageseinrichtungen für Kinder. Pluralisierung von Angeboten, München: Deutsches Jugendinstitut.

Dölling, Irene, Daphne Hahn and Sylka Scholz. 2000. "Birth strike in the new federal states: Is sterilization an act of resistance?”, in: S. Gal and G. Kligman, (eds.), Reproducing Gender: Politics, Publics, and Everyday Life after Socialism. Princeton: Princeton University Press, pp. 118-148.

Dorbritz, Jürgen and Karl Schwarz. 1996. "Kinderlosigkeit in Deutschland - ein Massenphänomen? Analysen zur Erscheinungsformen und Ursachen,” Zeitschrift für Bevölkerungswissenschaft 21(3): 231-261. 
Dorbritz, Jürgen. 1997. "Der demographische Wandel in Ostdeutschland - Verläufe und Erklärungsansätze”, Zeitschrift für Bevölkerungswissenschaft 22(2-3): 239-268.

Eberstadt, Nicholas. 1994. "Demographic shocks after communism: Eastern Germany, 1989-93”, Population and Development Review 20(1): 137-152.

Elder, Glen. 1985. "Perspective on the life course”, in: Glen Elder (ed.), Life Course Dynamics, Ithaca, pp. 23-49.

Fleischhacker, Jochen. 1994. "Im Westen stabil - im Osten instabil. Die ostdeutsche Bevölkerungsbewegung im Umbruch”, in: Hans-Ulrich Klose, (ed.), Alternde Bevölkerung - Wandel der Lebenswelten, Reihe: Forum Demographie und Politik: 3152.

Frejka, Tomas and Gérard Calot. 2001. "Cohort reproductive patterns in low-fertility countries”, Population and Development Review 27(1), 103-132.

Frerich, Johannes and Martin Frey. 1993. Handbuch der Geschichte der Sozialpolitik in Deutschland. Band 2: Sozialpolitik in der Deutschen Demokratischen Republik. München: Oldenbourg Verlag.

Hank, Karsten, Katja Tillmann and Gert Wagner. 2001. “Außerhäusliche Kinderbetreuung in Ostdeutschland vor und nach der Wiedervereinigung. Ein Vergleich mit Westdeutschland in den Jahren 1990 - 1999”, Zeitschrift für Bevölkerungswissenschaft 26(1): 55-65.

Höhn, Charlotte and Karl Schwarz. 1993. "Population policies and fertility trends in Germany: with a particular reference to the former German Democratic Republic”, in: H.P. David et al. (eds.), Demographic and Social Effects of Population Policies in Europe. Copenhagen: WHO, pp. 17-18.

Huinink, Johannes. 1989. "Das Zweite Kind. Sind wir auf dem Weg zur Ein-KindFamilie? ”, Zeitschrift für Soziologie, 18(3): 192-207.

Kharkova, Tatiana L. and Evgueny M. Andreev. 2000. "Did the economic crisis cause the fertility decline in Russia: evidence from the 1994 microcensus”, European Journal of Population 16(3), 211-233. 
Koch, Achim, Martina Wasmer, Janet Harkness and Evi Scholz. 2001. "Konzeption und Durchführung der Allgemeinen Bevölkerungsumfrage der Sozialwissenschaften (ALLBUS) 2000.” ZUMA Methodenbericht 2001/05.

Kohler, Hans-Peter and Dimiter Philipov. 2001. "Variance effects in the BongaartsFeeney formula”, Demography 38(1): 1-16.

Konietzka, Dirk and Michaela Kreyenfeld. 2002. “Women’s employment and nonmarital childbearing: a comparison between East and West Germany in the 1990s”, Population, 57(2) (forthcoming).

Kopp, Johannes. 2000. “Geburtenentwickung in Ost- und Westdeutschland. Trends, regionale Unterschiede, Erklärungen”, in: Hans Bertram, et al. (eds.), Solidarität, Lebensformen und regionale Entwicklung. Opladen: Leske und Budrich, pp. 82-135.

Kreyenfeld, Michaela and Johannes Huinink. 2002. “Der Übergang zum ersten und zweiten Kind. Ein Vergleich zwischen Mikrozensus und Familiensurvey”, in Jan Marbach and Walter Bien (eds.), Elternschaft und Geschlecht - Wandel und Entwicklung familialer Lebensformen in Deutschland, Opladen: Leske und Budrich, (forthcoming).

Kreyenfeld, Michaela, Katharina Spieß and Gert Wagner. 2002. “Kinderbetreuungspolitik in Deutschland”, Zeitschrift für Erziehungswissenschaft 5(2): 201-221.

Kreyenfeld, Michaela. 2002. “Time-squeeze, partner effect or self-selection? An investigation into the positive effect of women's education on second birth risks in West Germany”, Demographic Research 7(2): 15-48.

Kučera, Tomáš, Olga Kučerová, Oksana Opara and Eberhard Schaich (eds.). 2000. New Demographic Faces of Europe: The Changing Population Dynamics in Countries of Central and Eastern Europe. Berlin: Springer Verlag.

Lange, Thomas and Geoffrey Pugh. 1998. The Economics of German Unification: An Introduction. Cheltenhman: Edward Elgar.

Mau, Steffen and Wolfgang Zapf. 1998. “Zwischen Schock und Anpassung. Ostdeutsche Familienbildung im Übergang”, Informationsdienst Soziale Indikatoren 20: 1-4. 
Mau, Steffen. 1994. "Der demographische Wandel in den neuen Bundesländern. Familiengründung nach der Wende: Aufschub oder Verzicht? "Zeitschrift für Familienforschung 6(3): 197-220.

Mayer, Karl-Ulrich, Martin Diewald and Heike Solga. 1999. "Transitions to postcommunism in East Germany: Worklife mobility of woman and men between 1989 and 1993”, Acta Sociologica, 42(1): 35-53.

Mayer, Karl-Ulrich. 1997. "Notes on a comparative political economy of life courses", Comparative Social Research 16: 203-226.

Nauck, Bernhard and Magdalena Joos. 1995. "East joins west: child welfare and market reforms in the special case of the former GDR.” Innocenti Occasional Papers. Economic Policy Series 48. Florence: UNICEF International Child Development Centre.

Philipov, Dimiter. 2002. "Fertility in times of discontinuous societal change: The case of central and eastern Europe”, MPIDR Working Paper 2002-024.

Richter, Karin. 1993. “Geburtenentwicklung in den neuen Bundesländern. Auf dem Weg der Angleichung an die Muster der alten Bundesrepublik?“, Europa Dialoge: Zeitschrift für europäische Politik und Dialog 5(1): 21-27.

Sackmann, Reinhold and Matthias Wingens. 1996. "Berufsverläufe im Transformationsprozeß”, in: Martin Diewald and Karl-Ulrich Mayer (eds.), Zwischenbilanz der Vereinigung: Strukturwandel und Mobilität im Transformationsprozeß. Opladen: Leske und Budrich, pp. 11-31.

Schaich, Eberhard. 1998. "Der Geburteneinbruch in den neuen Bundesländern seit 1990 einige Hypothesen zu seiner Erklärung”, Jahrbücher für Nationalökonomie und Statistik 217(1): 93-107.

Schimpl-Neimanns, Bernhard. 2002. "Anwendungen und Erfahrungen mit dem Scientific Use File des Mikrozensus”, Zuma-Arbeitsbericht 2002/01.

Schwarze, Johannes and Gert G. Wagner. 2001. "Earning dynamics in the East German transition process”, in: Regina T. Riphahn et al. (eds.), Employment Policy in Transition: The Lessons of German Integration for the Labor Market. Berlin: Springer-Verlag, pp. 125-139. 
Statistisches Bundesamt. 1999. Bevölkerungsstatistische Übersichten 1946-1989. Teil V. Sonderreihe mit Beiträgen für das Gebiet der ehemaligen DDR, Heft 32. Wiesbaden: Statistisches Bundesamt.

Statistisches Bundesamt. 2001a. Bevölkerung und Erwerbstätigkeit. Gebiet und Bevölkerung 1999. Stuttgart: Metzler-Poeschel.

Statistisches Bundesamt. 2001b. Sozialleistungen. Tageseinrichtungen für Kinder 1998, Stuttgart: Metzler-Poeschel.

Statistisches Bundesamt. 2002. Erwerbstätigkeit, available under: http://www.destatis.de/basis/d/erwerb/erwerbtab4.htm

Störtzbach, Bernd. 1994. "Deutschland nach der Vereinigung - Meinungen und Einstellungen zu Familie, Kindern und zur Familienpolitik in Ost und West”, Zeitschrift für Bevölkerungswissenschaft 19(2): 151-167.

Trappe, Heike and Rachel A. Rosenfeld. 1998. “A comparison of job-shifting patterns in the former East Germany and the former West Germany”, European Sociological Review 14(4): 343-368.

Trappe, Heike and Rachel A. Rosenfeld. 2000. "How do children matter? A comparison of gender earnings inequality for young adults in the former East Germany and the former West Germany”, Journal of Marriage and the Family 62(2): 489-507.

Trappe, Heike. 1995. Emanzipation oder Zwang? Frauen in der DDR zwischen Beruf, Familie und Sozialpolitik. Berlin: Akademie Verlag.

Von Below, Susanne. 2000. "Regionale Ungleichheiten der Bildungschancen in den neuen Bundesländern”, in: Hans Bertram et al. (eds.), Solidarität, Lebensformen und regionale Entwicklung. Opladen: Leske und Budrich, pp. 199-223.

Wendt, Hartmut. 1991. “Geburtenhäufigkeit in beiden deutschen Staaten- zwischen Konvergenz und Divergenz”, Zeitschrift für Bevölkerungsforschung 17(3): 251-280.

Witte, James C. and Gert G. Wagner. 1995. "Declining fertility in East Germany after unification: A demographic response to socioeconomic change”, Population and Development Review 21(2): 387-397. 


\section{Tables \& Graphs}

Table 1: Availability ratio of public day care

\begin{tabular}{lrrrrrr}
\hline & \multicolumn{3}{c}{ West Germany } & \multicolumn{3}{c}{ East Germany } \\
& 1990 & 1994 & 1998 & 1990 & 1994 & 1998 \\
\hline Krippe (ages 0-3) & 2 & 2 & 3 & 56 & 41 & 36 \\
Kindergarten (ages 4-6) & n.a. & 14 & 19 & n.a. & 113 & 129 \\
Hort (ages 7-10) & 5 & 5 & 6 & 88 & 58 & 48 \\
\hline
\end{tabular}

Notes: (1) Availability ratio: available day care places per 100 children of an age group (2) n.a. $=$ not available $(3){ }^{*}$ only full-time care

Source: Deutsches Jugendinstitut (1993, 1998); Statistisches Bundesamt (2001b)

Table 2: Attitudes towards family life and female employment, in percent

\begin{tabular}{|c|c|c|c|c|c|c|}
\hline & \multicolumn{3}{|c|}{ West Germany } & \multicolumn{3}{|c|}{ East Germany } \\
\hline & 1992 & 1996 & 2000 & 1992 & 1996 & 2000 \\
\hline \multicolumn{7}{|c|}{ Child suffers when mother employed? ${ }^{*}$} \\
\hline Agree fully & 28 & 30 & 28 & 16 & 19 & 15 \\
\hline Agree partially & 35 & 37 & 37 & 23 & 27 & 21 \\
\hline Disagree partially & 24 & 22 & 23 & 33 & 25 & 41 \\
\hline Disagree fully & 10 & 9 & 12 & 25 & 26 & 22 \\
\hline Don’t know & 3 & 3 & 1 & 3 & 3 & 1 \\
\hline Number of valid cases & 492 & 540 & 402 & 208 & 195 & 220 \\
\hline \multicolumn{7}{|c|}{ Needs family to be happy? ${ }^{* *}$ ) } \\
\hline Needs family & 57 & 62 & 67 & 73 & 77 & 77 \\
\hline Alone as happy & 27 & 25 & 25 & 16 & 11 & 13 \\
\hline Alone happier & 2 & 2 & 1 & 1 & 3 & 1 \\
\hline Don’t know & 14 & 12 & 7 & 10 & 10 & 9 \\
\hline Number of valid cases & 492 & 541 & 402 & 207 & 195 & 220 \\
\hline \multicolumn{7}{|c|}{$\begin{array}{l}\left.\text { Notes: (1) For this analysis, we only used respondents of the birth cohorts } 1961-1970 .(2){ }^{*}\right) \text { The exact } \\
\text { wording of the question is as follows: A small child is most likely to suffer when the mother is working. } \\
\text { [Ein Kleinkind wird sicherlich darunter leiden, wenn seine Mutter berufstätig ist.] }(3){ }^{* *} \text { The exact } \\
\text { wording of the question is as follows: Do you think it requires a family to be happy? Or do you think that } \\
\text { it is possible to be just as happy by oneself? [Glauben Sie, daß man eine Familie braucht, um wirklich } \\
\text { glücklich zu sein, oder glauben Sie, man kann alleine genauso glücklich sein?] }\end{array}$} \\
\hline
\end{tabular}

Source: ALLBUS 1992, 1996, 2000 (own estimates) 
Figure 1: Total fertility rate in East and West Germany 1980-1999

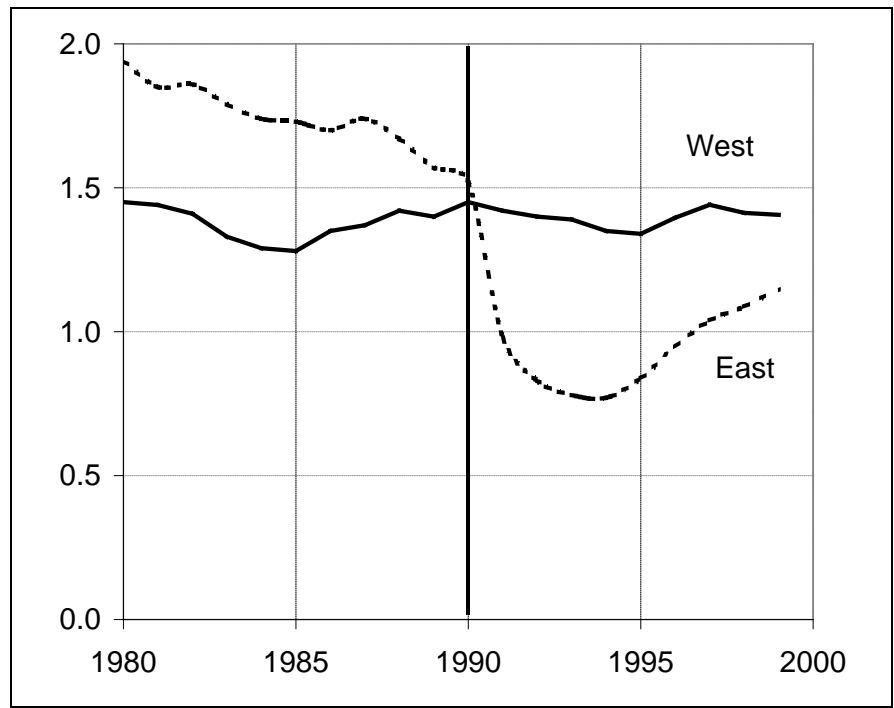

Source: Statistisches Bundesamt (2001a)

Figure 2: Unemployment rate in East and West Germany 1991-2000

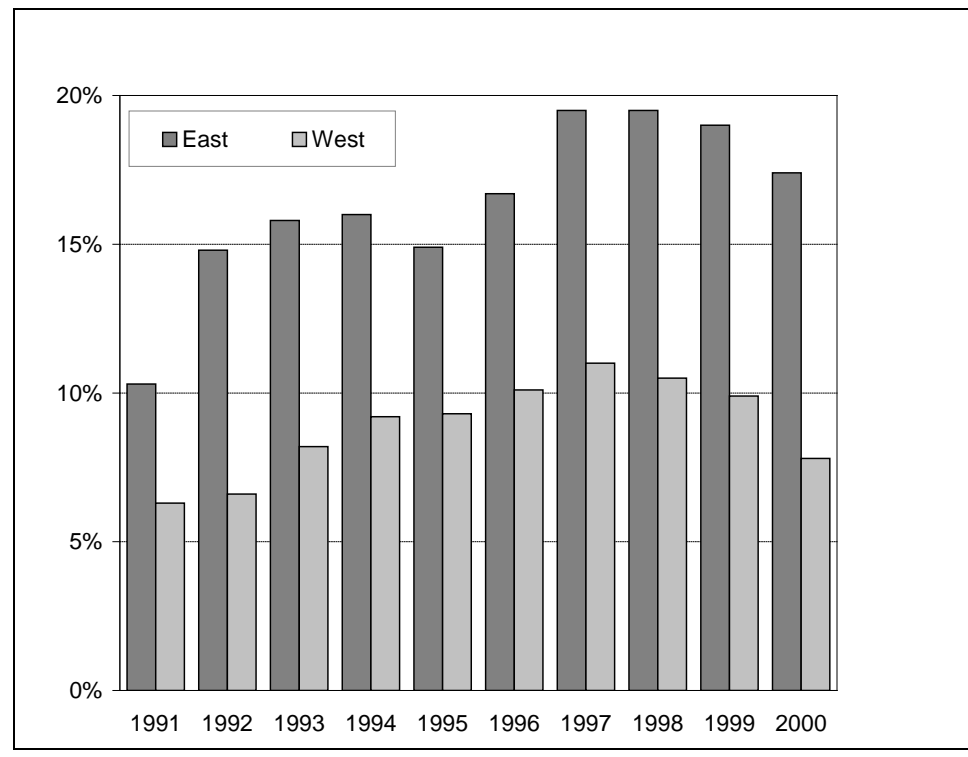

Source: Statistisches Bundesamt (2002) 
Figure 3: Transition to the first child, survival curves

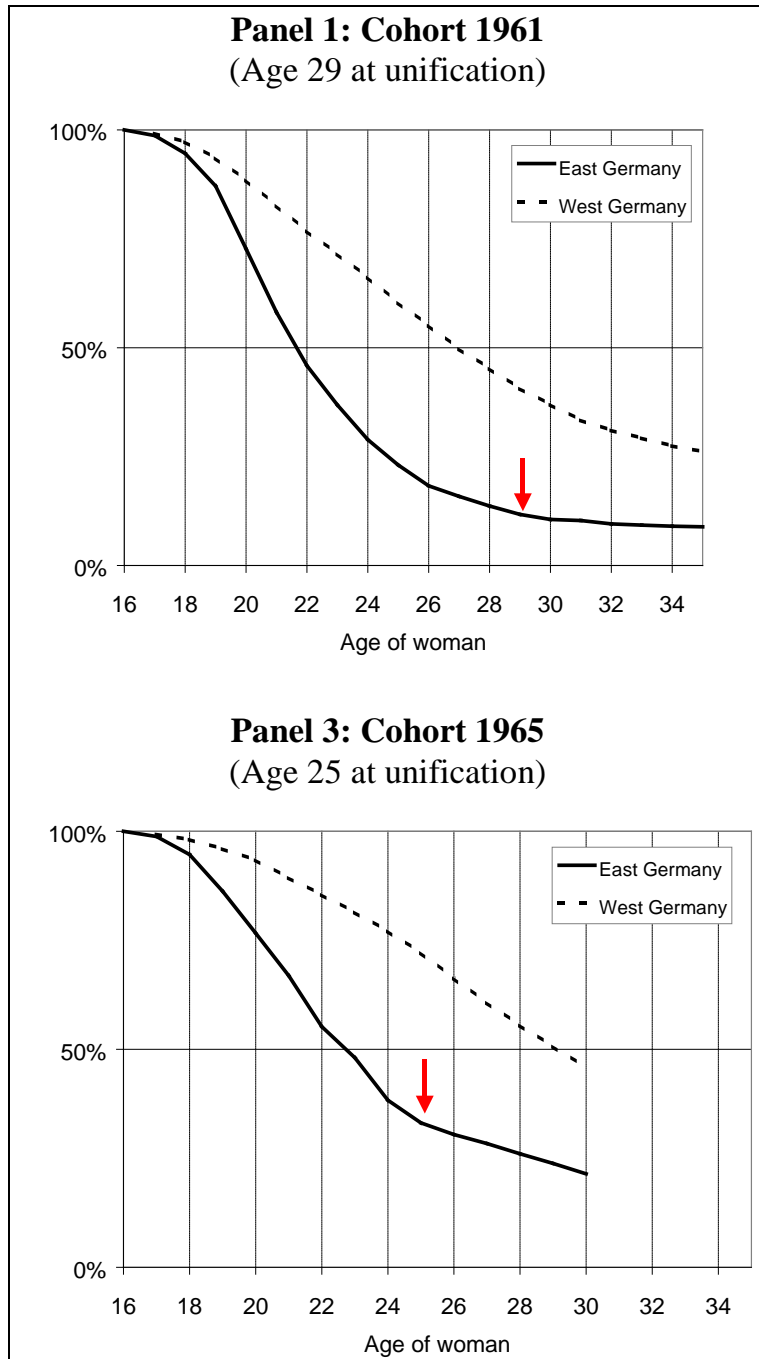

Panel 5: Cohort 1968

(Age 22 at unification)

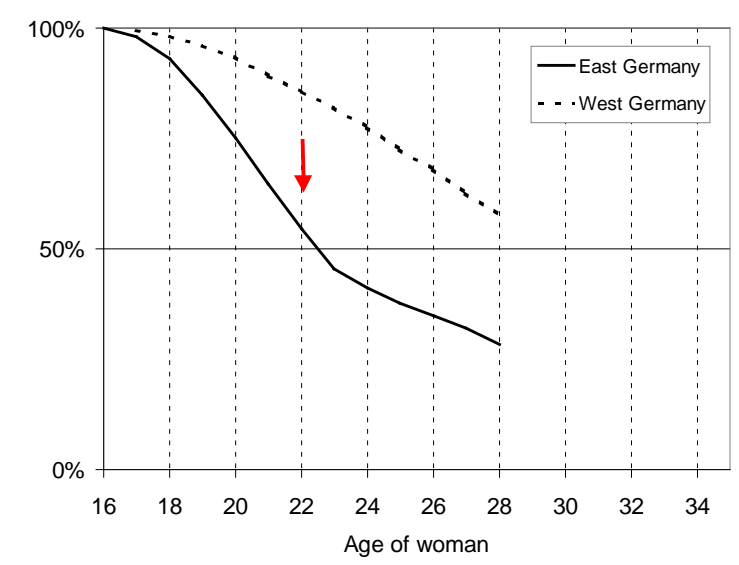

Panel 2: Cohort 1964

(Age 26 at unification)

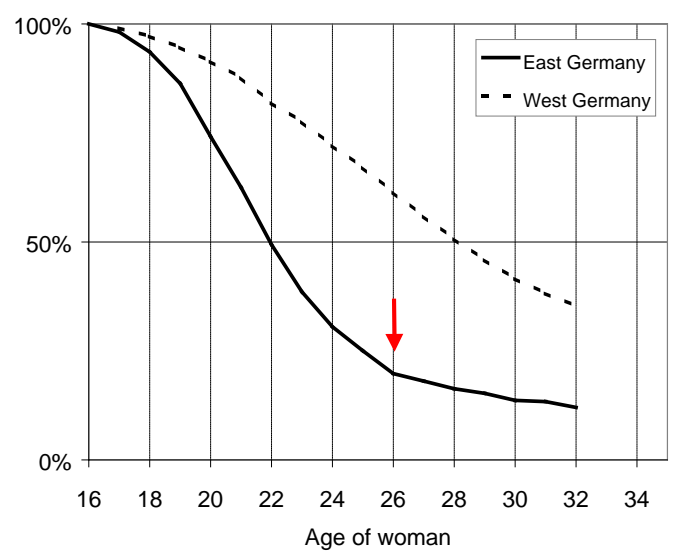

Panel 4: Cohort 1966

(Age 24 at unification)

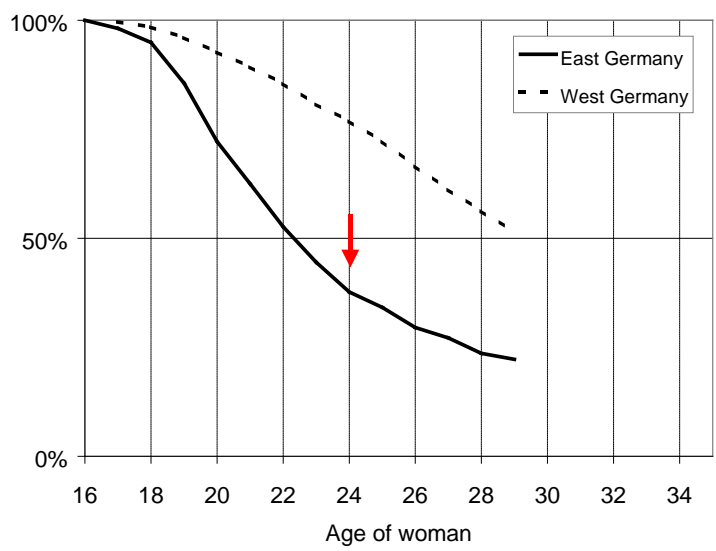

Panel 6: Cohort 1970

(Age 20 at unification)

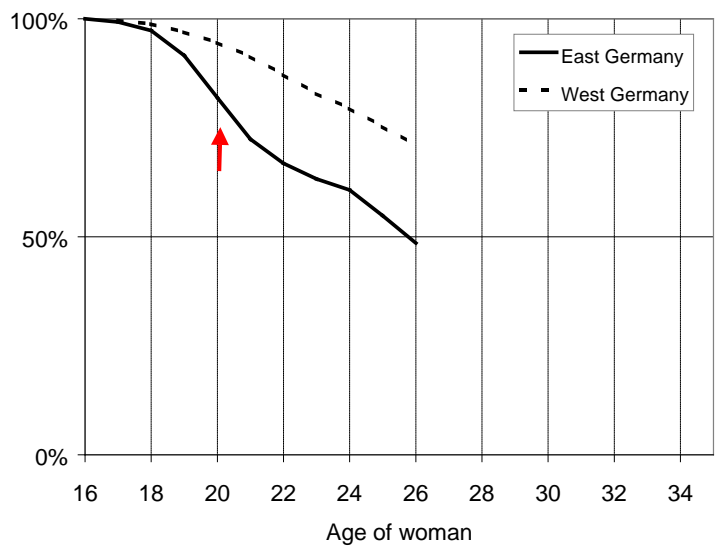

Notes: The arrow indicates the year of unification.

Source: German micro-census 1997 (own estimates) 
Figure 4: Transition to the first child, survival curves, women who are childless in 1990

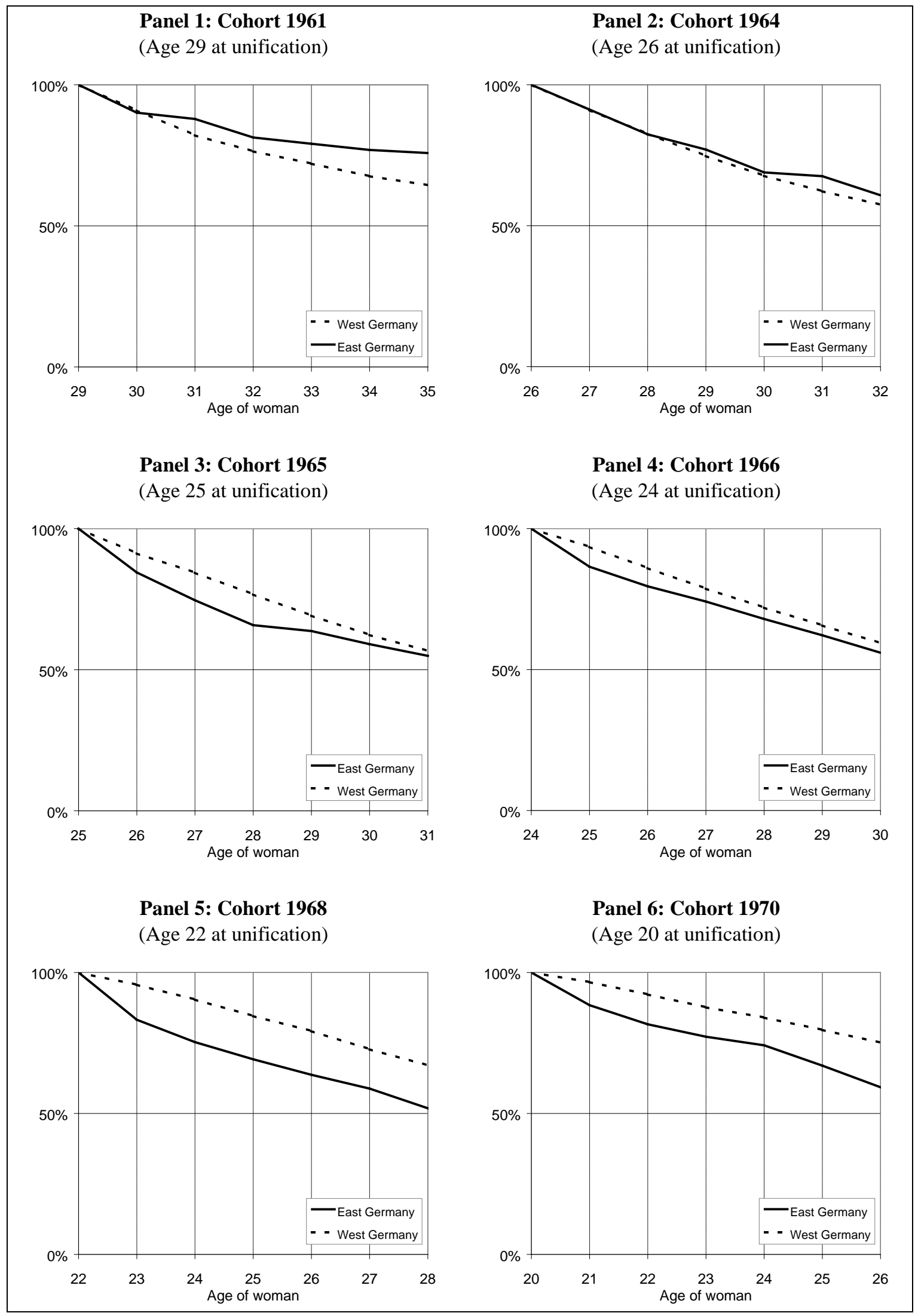

Source: German micro-census 1997 (own estimates) 
Figure 5: Transition to the first child, hazard rates

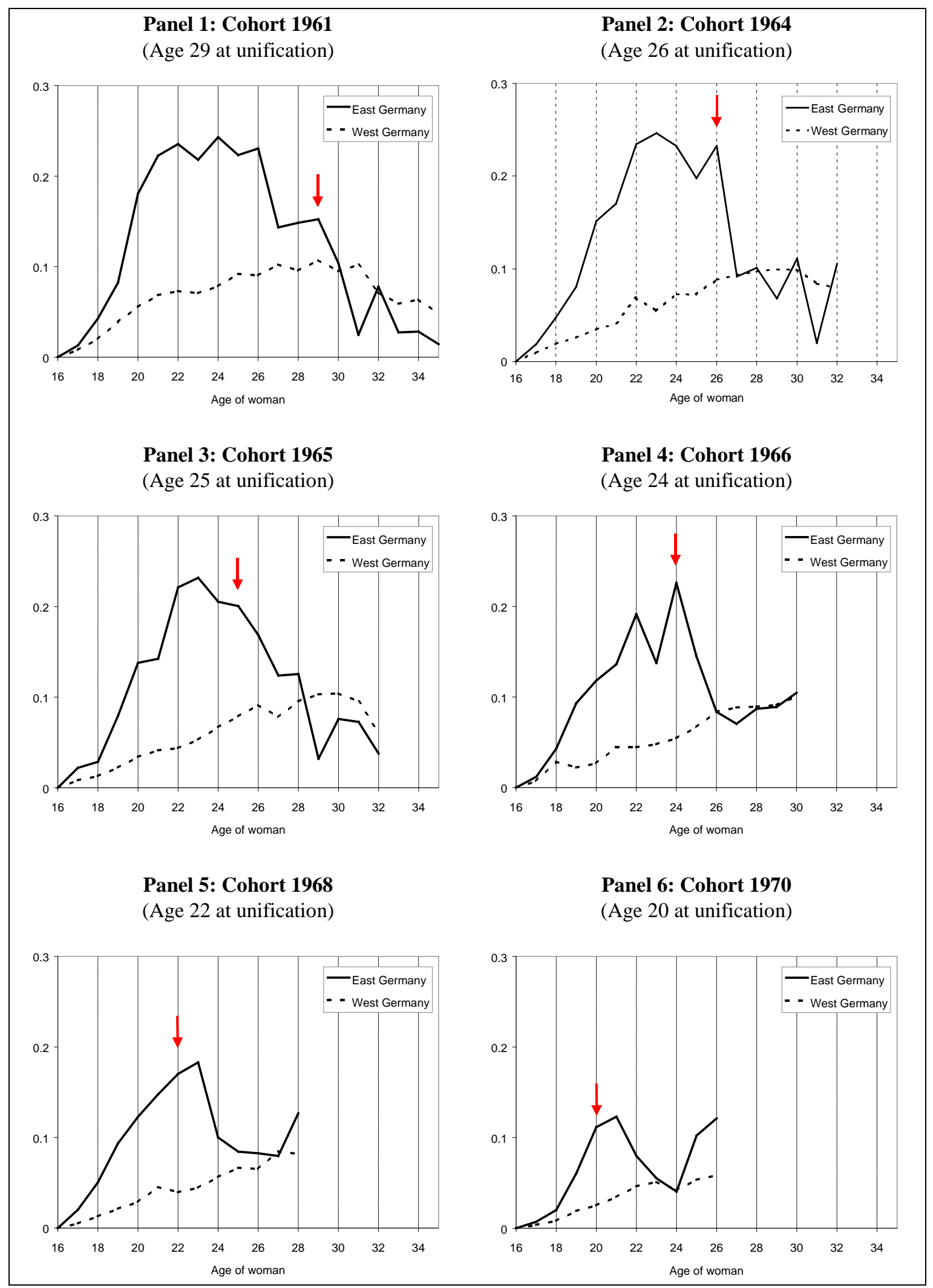

Notes: The arrow indicates the year of unification.

Source: German micro-census 1997 (own estimates) 
Figure 6: Transition to the second child before unification (right censored 1990)

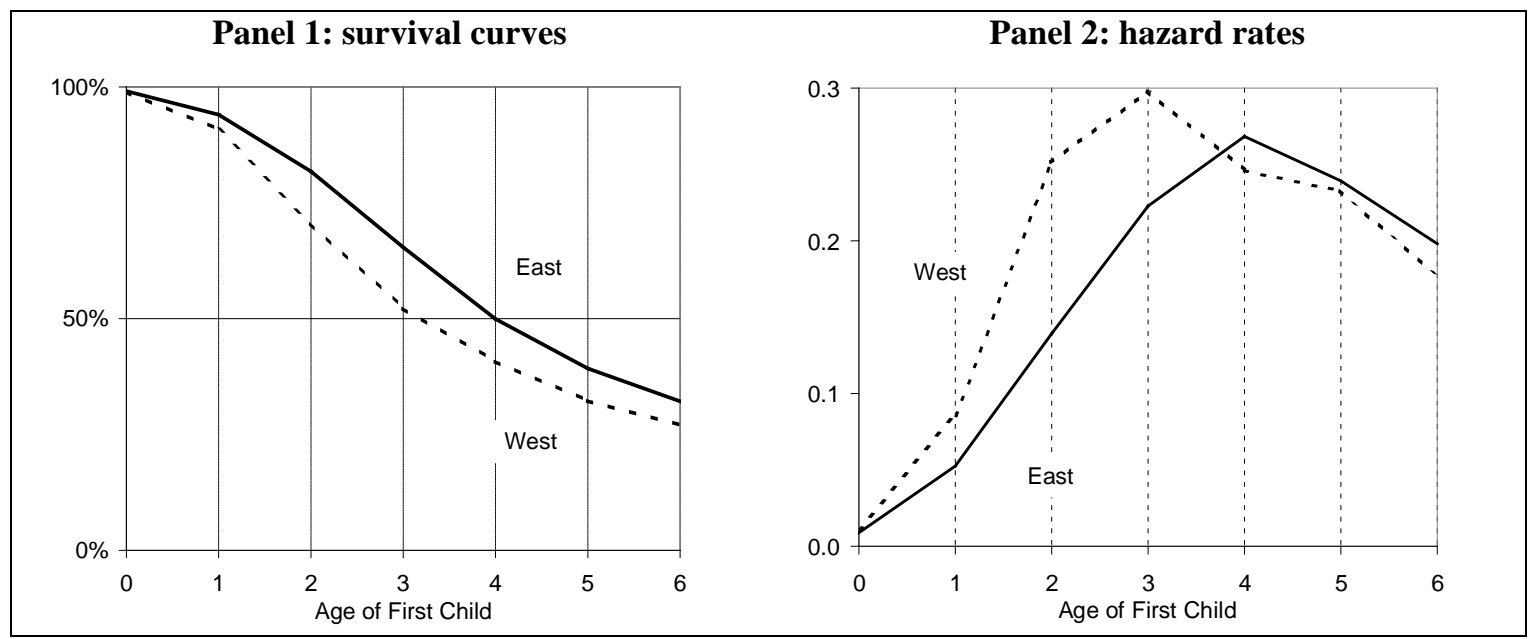

Notes: This analysis only covers respondents of the birth cohorts 1961-1970 who had a first child before 1990.

Source: German micro-census 1997 (own estimates)

Figure 7: Transition to the second child after unification

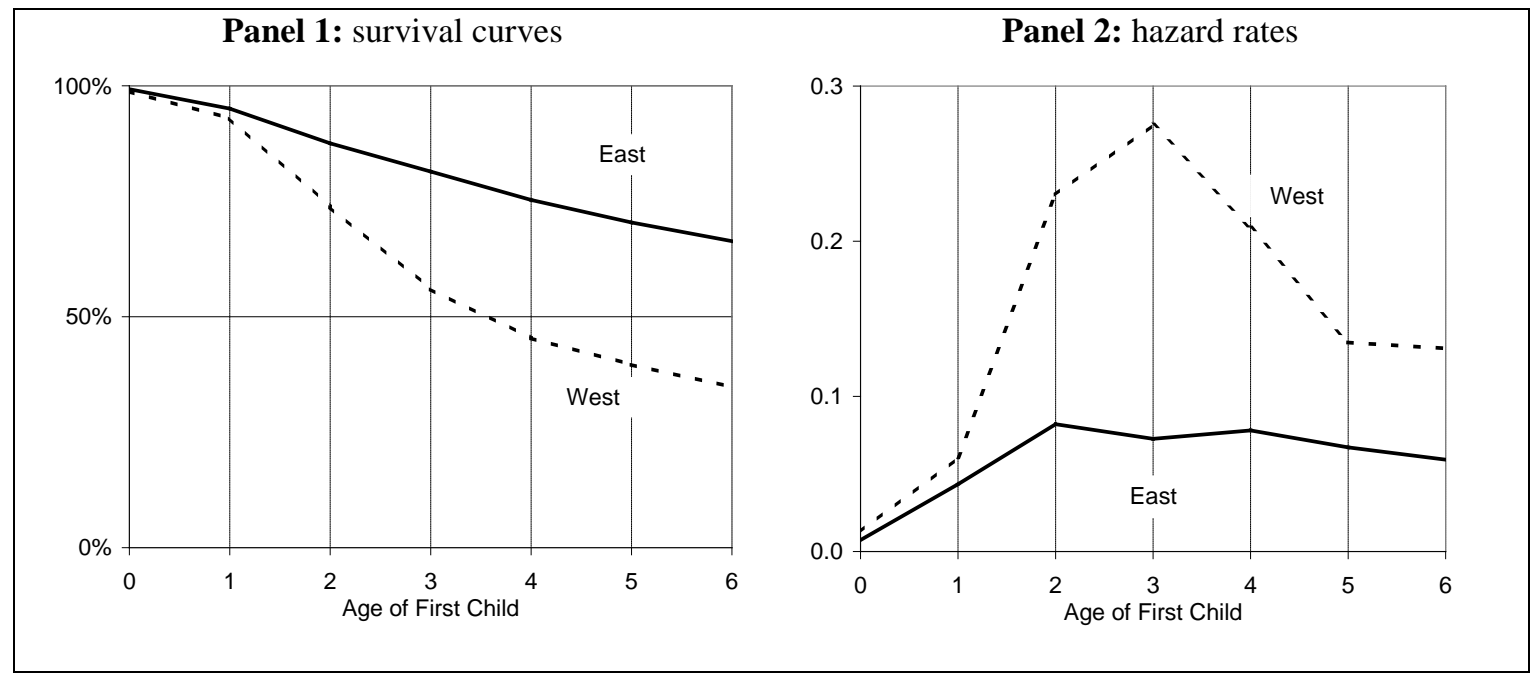

Notes: This analysis only covers respondents of the birth cohorts 1961-1970 who had a first child after unification.

Source: German micro-census 1997 (own estimates) 
Figure 8: Transition to the second child by year of first birth, survival curves

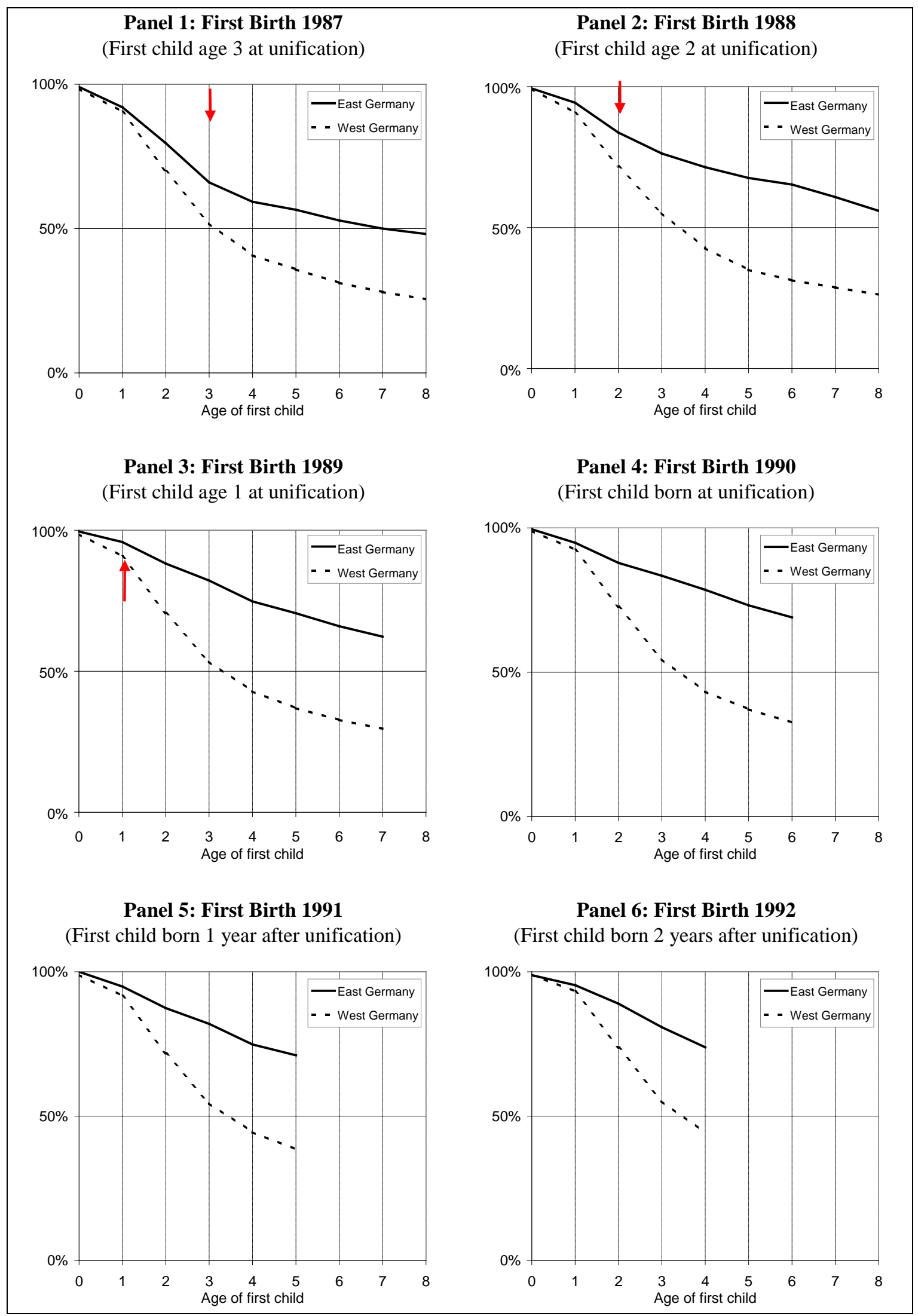

Notes: The arrow indicates the year of unification.

Source: German micro-census 1997 (own estimates) 
Figure 9: Transition to the second child by year of first birth, hazard rates

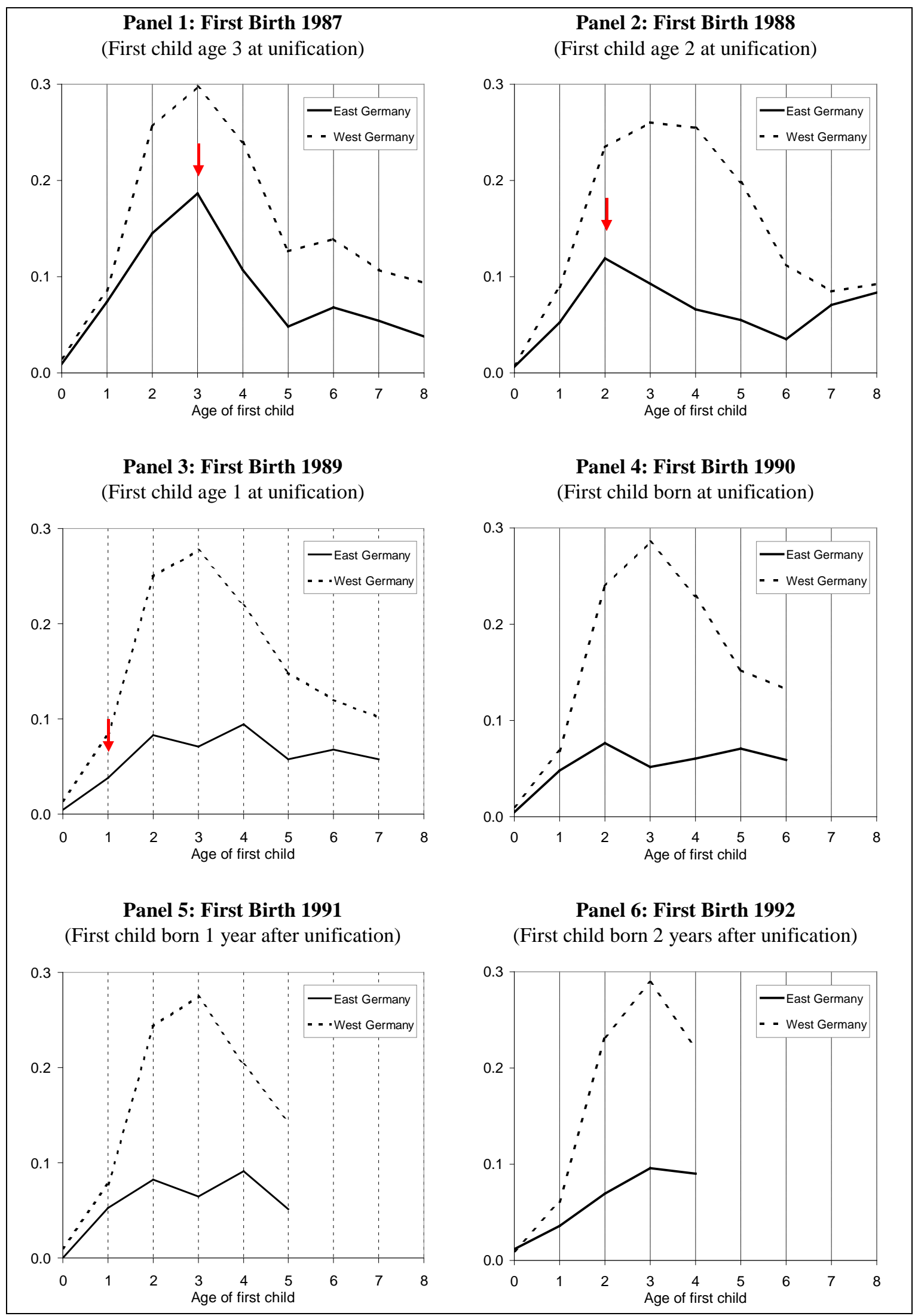

Notes: The arrow indicates the year of unification.

Source: German micro-census 1997 (own estimates) 


\section{Appendix}

Table A1: Sample size scientific-use file of the German micro-census, only women of the birth cohorts 1961-1970 who live in private households

\begin{tabular}{lcccccc}
\hline & \multicolumn{3}{c}{ West Germany } & \multicolumn{3}{c}{ East Germany } \\
Cohort & Respondents & First births & Second births & Respondents & First births & Second births \\
\hline 1961 & 3261 & 2424 & 1685 & 776 & 708 & 453 \\
1962 & 3196 & 2252 & 1510 & 771 & 684 & 436 \\
1963 & 3478 & 2425 & 1620 & 799 & 696 & 415 \\
1964 & 3330 & 2178 & 1322 & 747 & 659 & 363 \\
1965 & 3395 & 2095 & 1192 & 689 & 585 & 289 \\
1966 & 3309 & 1837 & 948 & 676 & 536 & 228 \\
1967 & 3142 & 1588 & 800 & 589 & 458 & 211 \\
1968 & 3183 & 1399 & 625 & 601 & 439 & 166 \\
1969 & 2982 & 1193 & 507 & 578 & 360 & 127 \\
1970 & 2688 & 833 & 327 & 558 & 296 & 78 \\
\hline
\end{tabular}




\section{Notes}

1 It is worth noting that there are also some differences in the educational system. In the East, primary school is still slightly shorter. In some East German states, the Abitur (A-level) only requires 12 years of education, while in most West German states 13 years are compulsory (von Below 2002). Furthermore, the percentage of college graduates is slightly lower, which can partially be explained by the lower density of universities and a smaller fraction of East Germans taking the Abitur.

2 The same applies to the cohorts 1967 and 1969, which are not displayed here.

3 They are significantly different on the 95-percent level. For improved readability of the graphs, we did however not display the confidence intervals.

4 A similar issue applies to the previous analysis (see Figure 6 and Figure 7). 